INTERNATIONAL JOURNAL OF RESEARCHES IN BIOSCIENCES, AGRICULTURE AND TECHNOLOGY (C) VISHWASHANTI MULTIPURPOSE SOCIETY (Global Peace Multipurpose Society) R. No. MH-659/13(N) www.vmsindia.org

\title{
GROWTH AND PRODUCTION OF CAROTENOIDS IN ANABAENA ORYZAE FRITSCH. IN DIFFERENT NUTRIENT MEDIA
}

\author{
J. N. Nehul \\ Dada Patil Rajale College, Adinathnagar Tal-Pathardi Dist-Ahmednagar- 414505(MS) India. \\ jnnehul@gmail.com
}

\begin{abstract}
:
Anabaena oryzae was isolated from the collected soil samples from different locations. Identification was carried out using morphological variation and taxonomical approaches according to Desikachary (1959).The axenic culture of Anabaena oryzaewas obtained in the laboratory .For the biomass production, different culture media were used namely BG-11, Fogg's medium, Allen and Arnon medium, Zarrouk's medium and CFTRI medium. The biomass was harvested by filtration through double layered muslin cloth and dried using air blower.After harvesting, the biomass obtained was subjected to the growth analysis.Carotenoids were estimated by spectrophotometer method according to Gowenlock (1988).Out of the different culture media used, BG-11 medium supported the growth of Anabaena oryzaeproperly as compared to other media used.The carotenoids content was more in Anabaena oryzaegrown in Fogg's medium followed by the BG-11 medium.
\end{abstract}

\section{Introduction}

Cyanobacteria (blue-green algae, BGA) are morphologically diverse group of phototrophic prokaryotes, which occur in almost every habitat on earth and useful to mankind in various ways (Thajuddin and Subramanian, 2005). They constitute a vast potential resource in varied applications such as food, feed, fuel, fertilizer, medicine, industry and in combating pollution (Thajuddin and Subramanian, 2005). Until past few decades of research, cyanobacteria were of academic interests and were mostly ignored as nuisance but, now are proved as potential organisms for much biotechnological utilization (Richmond, 1990; Sundararaman and Sekar, 2001; Thajuddin and Subramanian, 2005). The interest in these organisms as generators of pharmacologically active and industrially important compounds has been stimulated by recent results (Singh et al.,2002). A Variety of carotenoids produced by cyanobacteria have important commercial uses. Since carotenoids are non-toxic, they are desirable and used as coloring agents in the food industry (Bauernfeind, 1981). Carotenoids are frequently used in dietary additives for poultry and aquaculture farming (Hirschberg and Chamoritz, 1994).

\section{Materials and Methods}

Method of collection-The soil samples from 5$10 \mathrm{~cm}$ deep soil layers were collected using the scalpels. Soil samples were collected in polythene bags of size $6 \times 4$ inches.

Nutrient media-The different culture media namely BG-11 (Rippka et al., 1979); Fogg's medium 1949; Jacobson, 1951); Allen and Arnon's medium (Allen and Arnon, 1955); CFTRI medium (Venkataraman and Becker, 1984) and
Zarrouk's medium (Zarrouk, 1966) were used for the rich growth of Anabaena oryzae. These media were separately used in different sets.

Isolation of cyanobacterial species-The dry soil samples were spread in petri dishes and moistened with sterilized distilled water and cultures were incubated in light. When the visible growth of cyanobacteria begins to appear in the cultures, these cultures were used for the isolation of unialgal cultures of Anabaena oryzae.

Identification of the algal samples Morpohometric studies were carried out by using ocular and stage micrometer. The identification of Anabaena oryzaewas carried out using monograph and keys of Desikachary (1959).

Biomass production-For production of biomass, glass bottles (300 $\mathrm{mL}$ capacity) were used. The bottles were filled with $100 \mathrm{~mL}$ medium and autoclaved. The inoculum was ground in the sterile mortar and pestle in laminar air flow. Then the bottles were inoculated with $5 \mathrm{~mL}$ of unialgal suspension of Anabaena oryzaeand labeled properly. All the cultures were maintained in the culture room at temperature $28 \pm 2{ }^{\circ} \mathrm{C}$ under 8 -h light/ 16 -h dark photoperiod with a photosynthetic photon flux density of $40 \mu$ moles $^{-2} \mathrm{~S}^{-1}$ provided by cool white fluorescent tube lights .After harvesting, the biomass obtained was subjected to the growth analysis

Estimation of carotenoids-Carotenoids were estimated by spectrophotometer method according to Gowenlock (1988). Absorbance of carotenoids solution in $\mathrm{n}$ - hexane was determined at $440 \mathrm{~nm}$ and the amount was calculated by comparing with standard. The 
amount of carotenoids is expressed as \% on dry weight basis.

\section{Results and Discussion}

Out of the different culture media used, BG-11 medium supported the growth of Anabaena oryzae properly as compared to other media used. Allen and Arnon medium also supported growth but after 20 to 25 days, photo bleaching of biomass was observed. Other growth media, such as Fogg's medium and Zarrouk's medium supported the growth of Anabaena oryzaebut the growth rate was very slow.

Table : Influence of different media on growth and carotenoides in Anabaena oryzae.

\begin{tabular}{|c|l|c|c|c|}
\hline Sr.no & Medium & $\begin{array}{c}\text { Fresh } \\
\text { Weight }(\mathrm{g})\end{array}$ & $\begin{array}{c}\text { Dry } \\
\text { Weight }(\mathrm{g})\end{array}$ & $\begin{array}{c}\text { Carotenoids } \\
\%\end{array}$ \\
\hline 1 & BG-11 & $3.17 \pm 0.15^{\mathrm{a}}$ & $0.28 \pm 0.02^{\mathrm{a}}$ & $1.84 \pm 0.00^{\mathrm{b}}$ \\
\hline 2 & $\begin{array}{l}\text { Allen } 8 \\
\text { Amon }\end{array}$ & $2.82 \pm 0.16^{\mathrm{b}}$ & $0.26 \pm 0.03^{\mathrm{b}}$ & $1.54 \pm 0.01^{\mathrm{c}}$ \\
\hline 3 & $\begin{array}{l}\text { Fogg's } \\
\text { Medium }\end{array}$ & $2.34 \pm 0.19^{\mathrm{c}}$ & $0.20 \pm 0.05^{\mathrm{c}}$ & $2.53 \pm 0.00^{\mathrm{a}}$ \\
\hline 4 & $\begin{array}{l}\text { Zarrouk' } \\
\text { Medium }\end{array}$ & $2.32 \pm 0.23^{\mathrm{c}}$ & $0.19 \pm 0.01^{\mathrm{c}}$ & $1.44 \pm 0.00^{\mathrm{d}}$ \\
\hline 5 & CFTRI & $2.12 \pm 0.21^{\mathrm{d}}$ & $0.19 \pm 0.01^{\mathrm{c}}$ & $1.23 \pm 0.01^{\mathrm{e}}$ \\
\hline
\end{tabular}

Yield of biomass is one of the direct measures of quantity of biomass produced per unit area within a specific time. Higher yield indicates higher biomass produced per unit area. Comparison of Anabaena oryzae in different media showed that highest biomass per bottle in terms of dry weight was produced in BG-11 medium followed by Allen and Arnon medium. The carotenoids content was more in the Anabaena oryzae grown in Fogg's medium followed by the BG-11 medium. CFTRI medium showed poor response for the carotenoids content.

Cyanobacteria are photoautotrophic bacteria and require all the essential major and minor elements. The heterocystous cyanobacteria fix atmospheric nitrogen and they can use atmospheric nitrogen as a source of nitrogen. In bottles, the medium does not come in contact with atmospheric nitrogen and the source needs to be added in the culture medium. If the culture medium is devoid of nitrogen, it results in poor growth of cyanobacteria. Similar results were reported by Olatz (1991); medium lacking nitrogen source, results in yellowish green color of the cells which is a characteristic of nitrogen deficiency. In the culture methods like photo- bioreactors, pure nitrogen is continuously bubbled into culture medium, (Humberto et al., 1989; Vonshak, 1993; Roxana et al., 2000) so that cultures do not get affected due to nitrogen deficiency.
The growth of Anabaena oryzaewas more in BG-11 medium than in other media. For optimum growth of cyanobacteria, appropriate $\mathrm{Ka}^{+}: \mathrm{Na}^{+}$ratio is required in the cytoplasm. High $\mathrm{Na}^{+}$is required by nitrogen fixing cyanobacteria for conversion of molecular nitrogen into ammonia (Becker, 1994). BG-11 medium consists moderate concentration of $\mathrm{Na}^{+}$ and in Allen and Arnon medium, Zarrouk's medium and CFTRI medium there is high concentration of $\mathrm{Na}^{+}$while in Fogg's medium; there is no $\mathrm{Na}^{+}$source. Anabaena oryzae is from moist soil habitat, which may not require high concentration of $\mathrm{Na}^{+}$ions in the medium.

Production of pigments depends on composition of medium and its $\mathrm{pH}$. In Fogg's medium composition and $\mathrm{pH}$ is moderate which resulted in higher accumulation of carotenoides in the biomass of Anabaena oryzae.Cifuentes and co-workers (1996 a,b) demonstrated that low nitrogen content results in higher accumulation of carotenoides in Dunaliella sp.This response can be explained by the wellknown effect of limitation in this nutrient as an inductive factor of carotenogenesis in Dunaliella (Ben-Amotz et al., 1982) .Fogg's medium does not contain nitrogen source, therefore the higher production of carotenoides may be due to low nitrogen content of the medium.

\section{References}

1. Allen MB, Arnon DI (1955) Studies on nitrogen fixing blue green algae. I. Growth and nitrogen fixation in Anabaena cylindrica.Plant Physiol. 30:366-372

2. Bauernfeind JC (1981) Carotenoidsascolorants and Vitamins A Precursors. London: Academic Press

3. Becker EW (1994) In: Microalgae Biotechnology and Microbiology, Cambridge, Cambridge University Press, ISBN 0- 521 35020-4, pp 1-4

4. Ben-Amotz A, Katz A, Avron M (1982) Accumulation of b-carotene in halotolerant algae: purification and characterization of $b-$ carotene-rich globules from Dunaliella bardawil (Chlorophyceae). J Phycol 18:529-537

5. Cifuentes A, González M, Parra O (1996a). The effect of salinity on the growth and carotenogenesis in two Chilean strains of Dunaliella salina Teodoresco. Biol Res 29: 227236

6. Cifuentes A, González M, Parra O, Zúñiga M (1996b) Cultivo de cepas de Dunaliella salina (Teodoresco 1905) en diferentes medios bajo condiciones de laboratorio. Rev Chilena Hist Nat 69: $105-112$

7. Desikachary TV (1959) A monograph on Cyanophyta, ICAR Publication, New Delhi.1-686 
8. Fogg GE (1949) Growth and heterocyst production in Anabaenacylindrica Lemm. II. In relation to carbon and nitrogen metabolism. Ann. Bot. 13: 241-259

9. Gowenlock AH (1988) Varley's Practical Clinical Biochemistry. Sixth edition. London; Heineman Medical Books, 407-420

10. Hirschberg J, Chamoritz D (1994) In: The Molecular Biology of Cyanobacteria, (Ed.). Bryant, DADordrecht, The Netherlands: Kluwer Academic Publishers.pp.559-579

11. Humberto J, Silva IC, Rodolfo JE (1989). Effect of nutritional factors on the culture of Nostoc sp.as a source of phycobiliprotiens. Appl Microbiol Biotechnol 31: 293-297

12.Jacobson L (1951) Maintenance of iron supply in nutrient solutions by a single addition of ferric potassium ethylene diamine tetra-acetate. Plant Physiology 26: 411-413

13. Olatz F, Ramon G, Juan LS (1991) Carotenoides composition in the Cyanobacterium Phormidiumlaminosum. Effect of nitrogen starvation. FEBS Letters, 282: 300-304

14.Richmond A (1990) In: Algal Biotechnology, (Eds.). Round FE, Chapman DJ, Bristol UK: Biopress Ltd. pp. 269-330

15. Rippka R, Deruelles J, Waterbury JB, Herd man M, Stainer RY (1979) Generic assignments. Strain histories and properties of pure cultures of cyanobacteria. J. Gen. Microbiol. 111: 1-61

16. Roxana Olvera-Ramirez, Marisela Coria-Cedillo, Rosa Olivia Canizares-Villanuevea Fernando Martinez-Jeronimo, Teresa Ponce-Noyola, Elivira Rios-Leal,(2000). Growth evaluation and byproduct characterization of Calothrix sp. Bioresource Technology 72: 121-124

17.Singh DP, Tyagi MB, Kumar A, Prasuna EG (2002) Bioactive Secondary Metabolites from cyanobacteria. Pg.275-292. In Algological research in India. Edt. N. Anand, Pbl. Bsmps Dehradun. India

18. Sundararaman M, Sekar S (2001) Biotechnological potential of cyanobacteria. In: Algal biotechnology, Trivedi PC (ed.), Pointer Publishers, Jaipur, India. pp 31-52

19.Thajuddin N, Subramanian G (2005) Cyanobacterial biodiversity and potential applications in biotechnology, Curr. Sci. 89: 4757

20.Venkatarama, LV, Becker EW (1984) Production and utilization of the blue-green alga Spirulina in India. Biomass4: 105-125

21.Vonshak A (1993) Spirulina platensis (Arthrospira): Physiology, Cell Biology and Biotechnology. Taylor \&Francis, London. ISBN 0-7484-0674-3

22.Zarrouk C (1966) Contribution a l'etude d'une cyanophycee. Influence de divers' facteurs physiques et chimiques sur la croissance et la photosyntheses de Spirulinamaxima. Ph.D.Thesis. University of Paris, France. 